\title{
The policy narratives of European Capital Markets Union
}

Lucia Quaglia, Department of Political Science, University of Bologna, Bologna, Italy;

David Howarth, Institute of Political Science, University of Luxembourg.

NB. This is the authors' pre-print of the final article. Please reference this article as: Quaglia, L. \& Howarth, D. (2018) 'The policy narratives of European capital markets union', Journal of European Public Policy, 25 (7), pp. 990-1009.

\begin{abstract}
This paper examines the 'making' of Capital Markets Union (CMU) through the theoretical lens of 'actor-centred constructivism', by considering the 'policy narratives' that bureaucratic actors have employed strategically to promote the project. It is argued that two main narratives were articulated by the European Commission in order to mobilise the political support necessary to push forward CMU and reduce potential opposition to it. The first narrative was to boost the size and internal and external competitiveness of EU capital markets. The second narrative was the increased funding to the real economy, especially to Small and Medium Enterprises (SMEs) and infrastructural projects. The Commission used these narratives instrumentally in 'framing' CMU as a positive-sum game, rather than a zero-sum game with potential winners and losers.
\end{abstract}

Keywords: Capital Markets Union (CMU), financial regulation, financial markets, financial integration, single market 


\section{Introduction}

Shortly after the agreement on most of the elements of Banking Union, the European Commission embarked on a new project, 'Capital Markets Union' (CMU). The stated objectives of CMU were 'to create deeper and more integrated capital markets' in the 28 member states of the European Union (EU) and to expand the 'non-bank part of Europe's financial system' (Véron 2014: 1). CMU is important economically and politically for several inter-related reasons. CMU was intended to advance the single market in finance, to revamp credit growth in the EU after the crisis, to 'counter-balance' Banking Union (especially in the eyes of euro area outsiders, notably the UK) and to further the completion of Economic and Monetary Union (EMU). CMU could potentially diminish the reliance on predominantly bank-based sources of funding for the real economy in the EU. CMU is officially about the liberalisation and opening up of national financial systems, which are one important element of national varieties of capitalism. CMU is thus an important project for both policy-makers but also for academics working on European market integration - it is about the future development of the single market and national markets. After Banking Union, CMU was officially the EU's next big economic project and was highlighted by Commission President Jean-Claude Juncker as the highest priority of his term as Commission president.

CMU poses two interesting puzzles. First, the literature on the new intergovernmentalism stresses the limited influence of the Commission in several policy areas (Bickerton et al. 2015). Indeed, the Commission was a marginal actor during the sovereign debt crisis (Schimmelfennig 2015) and in the construction of Banking Union (Howarth and Quaglia 2016). Yet, the Commission was the primum mobile in the making of CMU, as explained in this paper. Second, the literature on EU financial reforms over the last decade considers EU 
post crisis financial regulation primarily as 'market-shaping' (Quaglia 2010, 2012). By contrast, CMU is mostly 'market-making'. Notably, it aims to promote securitisation which gained a bad reputation during the crisis - simplify the prospectus for firms that want to list on regulated markets — thus facilitating cross-border investment — and lower capital requirements for insurers.

We argue that by examining the policy narratives articulated by the Commission we can account for its success at the agenda setting stage (2014-16) and we can make sense of why CMU was put on the agenda in the way that it was. The definition and priorities agreed during the agenda setting stage informed most of the specific EU measures subsequently adopted to establish CMU. The Commission strategy was particularly important because the CMU project was perceived in many member states in terms of winners and losers. In the past, the member states that feared the implications of financial market integration sought to slow it down. Theoretically, our work speaks to the literature on ideas in EU public policy and actor-centred constructivism (most recently, see Carstensen and Schmidt 2016; Saurugger 2013), arguing that actors can strategically use parallel narratives that target a variety of audiences with a view to promoting a certain policy project. Empirically, our work contributes to the study of the construction of the Single Market (Bulmer and Armstrong 1998, Donnelly 2010, Egan 2001), especially in finance (Mügge 2010; Quaglia 2010), including work that specifically examines 'policy narratives' (Jabko 2006, 1999; Radaelli 1999).

Specifically, we argue that the European Commission sought to promote CMU by articulating two narratives, which targeted different audiences, in order to mobilise the political support of the member states, financial industry, and the nonfinancial sector. The 
first narrative centred upon boosting the size and the internal and external competitiveness of EU capital markets. The Commission directed this narrative above all at the British government (aligned largely with the City of London), and the financial industry in a number of EU member states and specifically large cross-border banks. The second Commission narrative focused upon the provision of increased funding to the real economy, especially to small and medium enterprises (SMEs) and infrastructural projects. This narrative was instrumental in order to mobilise the support of most continental member states and notably in the EU periphery. In wielding both narratives, the Commission portrayed CMU as a positive sum (win-win) game that benefitted everyone — rather than as a project generating potential winners and losers - thus reducing potential opposition to it. The Commission's narrative of 'everyone is a winner' sought to blur the potential political economy effects of capital market liberalisation.

This article is organised as follows. The next section reviews the literature on ideas in analysing EU public policies and outlines our core argument that informs the analysis of the subsequent empirical sections. We then discuss the pivotal role of the Commission in the development of the CMU project and examine the political economy of CMU. The penultimate section presents the two main narratives articulated by the European Commission in order to mobilise the political support necessary to push forward CMU.

\section{Ideas and actor-centred constructivism in EU public policies}

Over the last thirty years or so, there has been a burgeoning constructivist research agenda in the study of EU public policy (for a comprehensive discussion, see Saurugger 2013). 'Actorcentred constructivism' has been particularly prominent in the field of European political 
economy ${ }^{1}$ as it considers not only ideas, but also actors, interests and power, thus addressing some traditional critiques of constructivism (Saurugger 2013: 897). A variety of ideas-based approaches can be subsumed under the label of actor-centred constructivism: 'policy learning' (Radaelli and Dunlop 2013), 'policy framing' (Surel 2000), 'advocacy coalition' (Sabatier 1998), 'discursive institutionalism' (Schmidt 2008), and 'strategic constructivism' (Jabko 2006, 1999). A vast array of related concepts has been deployed in order to examine EU public policies, notably: 'policy paradigms' concerning macroeconomic policies (McNamara 1998) and financial regulation (Mügge 2011; Quaglia 2010); 'policy narratives' concerning taxation (Radaelli 1999); 'discursive constructions' on 'globalisation' (Hay and Rosamond 2002). Schmidt (2008) distinguishes between the 'coordinative' discourse that takes place amongst policy-makers and the 'communicative' discourse of policy-makers who present policy programmes to the general public. Recent research has specifically explored the link between 'ideas' and 'power', discussing 'power in, over and through' ideas (Carstensen and Schmidt 2015: 318).

Here, we are particularly interested in a 'strategic' form of actor-centred constructivism, whereby ideas are deliberately promoted, kept off the agenda, or strategically used by actors in order to frame (or re-frame) interests, form supporting coalitions, and prevent opposition to certain projects. For example, Jabko (2006) analyses how the European Commission manipulated the idea of the 'market' in various ways in order to build coalitions in favour of the construction of the Single Market. He also highlights the specific 'logics' deployed by the Commission in order promote EMU (Jabko 1999). Radaelli (1999) traces how the 'narrative' of 'harmful tax competition' was purposefully deployed by the Commission in the field of taxation policy, traditionally the realm of the member states. 
Actors (especially, the Commission) are likely to deploy ideas strategically in order to frame (or reframe) interests, if the proposed project is likely to meet some opposition amongst or within EU member states. In turn, this is more likely to happen in the case of economic policies, where there are entrenched interests at stake and (self-)perceived winners and losers. For example, over the previous two decades, national governments had repeatedly been keen to agree EU-level regulation that was most advantageous for their national financial systems, which frequently produced deadlock in negotiations (Mügge 2010; Quaglia 2010). In the construction of CMU, conflicting financial interests are at stake, which reflect the different configuration of national financial sectors and their link to the real economy (see Quaglia et al. 2016), as explained in the empirical analysis below. In order to side-step opposition from potential losers and avoid policy deadlocks, agents can develop policy narratives, which are causal stories relevant to policy-making (Radaelli 1999) and which are instrumental in mobilising support for a given project by framing it in a certain way. Often one prevailing policy narrative, such as that of 'harmful tax competition' (Radaelli 1999) is deployed for persuasive purposes. Less frequently, parallel narratives are used to speak to different audiences and frame a certain policy project as a positive sum game, not as a competitive zero-sum game with winners and losers.

With reference to CMU, power dynamics alone cannot account for the launch of the project and the shape it took. It is true that - as explained in Section 4 below - there were a set of actors with strong interests in CMU, notably large universal banks, the City of London and the UK authorities; and a rather loose coalition of less enthusiastic actors, mainly smaller traditional banks, Small and Medium Sized Enterprises, and governments in Southern and Central and Eastern Europe. Yet, the first set of actors had been mostly on the losing side when EU market-shaping financial regulation was adopted post crisis. Moreover, the second 
set of actors were more numerous, albeit less well-organised. One could argue that the 'vagueness' of what was meant by CMU contributed to increase support and lessen opposition. Yet, the under-specified nature of CMU was (partly) a result of how this policy initiative was framed by the Commission.

We argue that the Commission's policy narratives were instrumental in constructing the benefits of CMU for these different players in order to push the project forward. In order to develop this argument, we first examine the empirical record of the development of CMU looking for evidence that the Commission was the leading institutional promoter of CMU. We then examine the political economy of CMU. Finally, we tease out the main elements of the Commission's narratives by examining the key CMU-related documents and speeches in Brussels launching them because these - by virtue of their wider audience — contain both policy narratives. We then focus on all the speeches, print interviews and written articles that focused principally on CMU and were produced by and for Commission officials. These speeches, interviews and articles targeted a variety of audiences in the United Kingdom, Germany and France, as well as economic interest groups in these three member states and in Brussels. The material gathered covers the period June 2014 to December 2016. The Commissioner directly responsible for CMU — Lord Jonathan Hill — made the bulk of these speeches and interviews and officially authored all of the articles that focused principally on CMU. It is noteworthy that Commissioner Hill — despite his reputation as a Thatcherite liberal and defender of City interests - changed his narrative to suit his audience. In many of his CMU speeches on the continent, Hill emphasised the importance of the project to improve the financing of SMEs and infrastructural projects, as elaborated below.

\section{The Commission and the making of CMU}


The Commission was the main driver of CMU — it first proposed and promoted it. The idea of CMU was first mentioned in the Political Guidelines for the next European Commission presented to the European Parliament in July 2014 by the former Luxembourg Prime Minister, Jean-Claude Juncker — then candidate for Commission President (Juncker 2014: 7 and 19). In addition to 'completing' EMU and 'complementing' Banking Union, the new Commission officially presented the CMU project as fully in line with the 'Investment Plan for Europe' (also known as the 'Juncker Plan' 2014) of November 2014. In February 2015, the Commission published the Green Paper 'Building a Capital Markets Union', which was subject to a public consultation (Commission 2015a). At that stage, CMU was a 'mixed bag': a 'long shopping list' of necessary measures to adopt in order to complete the single financial market and boost EU capital markets. In September 2015, the Commission put forward an Action Plan for CMU (Commission 2015b).

The first substantive building block of CMU put forward by the Commission in September 2015, was a package of two legislative proposals: a 'Securitisation Regulation' that set out criteria for 'Simple, Transparent and Standardised Securitisations'; and a proposal to amend the Capital Requirements Regulation to make the capital treatment of securitisations for banks and investment firms more risk-sensitive (effectively to lower capital requirements). Furthermore, the Commission began preparing a proposal for the revision of the Prospectus directive and the Solvency II directive. It opened a consultation on venture capital and social entrepreneurship funds, a consultation on covered bonds in the EU, and a call for evidence on the EU regulatory framework for financial services. After the idea of CMU was aired by the would-be President of the Commission Juncker in July 2014, it was then elaborated and promoted by the newly created Commissioner for 'Financial Stability, Financial Services and 
Capital Markets Union', the British Conservative peer Jonathan Hill, and his team.

The empirical record suggests that the Commission was the initial promoter of CMU. Although the Commission informally consulted the main policy stakeholders on their views before officially proposing CMU, there is no evidence that any member state governments or elements of the financial industry spurred the Commission into action. The documents issued by the national authorities and industry associations all post-dated the Commission's proposals and were mainly a response to what was proposed, as elaborated in the following section. Thus, member state governments and the financial industry subsequently contributed to shaping CMU. National governments did so through their responses to official Commission consultations and then decision-making in the Council. The financial industry did so through its responses to the consultations and lobbying activities.

However, the Commission had considerable room for manoeuvre at the agenda-setting stage to develop what was meant by CMU and its priorities. This was crucial in shaping the subsequent development of the project and the legislative and non-legislative measures adopted. The Commission was keen to promote CMU for its 'intrinsic' merits (as detailed in many Commission's documents), but also as a way to relaunch financial integration in Europe. There was also a political motivation related to the referendum on Brexit, in that CMU was a project that would greatly benefit the City of London and would therefore attract the support of the British authorities (Ringe 2015), as explained in the following section.

\section{The political economy of CMU: potential winners and losers}


CMU — especially if all its main elements are eventually adopted — would have competitive implications for much of the financial sector and for member states. In other words, CMU would likely generate winners and losers or, at the very least, some players would benefit more than others (for a detailed analysis, see Quaglia et al. 2016). The underlying political economy conflict concerning CMU was both at the level of economic interests (different financial firms) and member states (with differently configured financial systems and economies). At the level of economic interests, CMU potentially created an advantage for non-bank financial firms and larger universal banks which had the resources to engage in non-traditional banking activities (including securitisation, see Gabor 2015). More traditional and often smaller banks that were less engaged in capital markets and securitisation were potentially disadvantaged. CMU was explicitly about increasing the choices available to nonfinancial companies (notably SMEs) in need of external funding — beyond bank credit.

At the level of conflict among member states, CMU promoted the opening up of national financial systems: their diversification and, inevitably, denationalisation. The large majority of EU member states had financial systems overwhelmingly dominated by banks, providing the bulk of external funding to non-financial firms. Several West European financial systems — notably, the German, French, Italian, Spanish, Dutch and Swedish — also had financial systems dominated overwhelmingly by nationally-owned banks. Thus, CMU represented a potentially significant force for change both in economic but also in political terms, given the political significance of national bank champions in a number of EU member states (Epstein 2017).

Only a small number of member states — notably the United Kingdom and Luxembourg had diverse financial systems where more than a third of financial assets were held by 
financial institutions other than banks. Furthermore, only in the UK did non-financial company external funding extend significantly beyond bank credit for more than the largest national companies. Member states in which smaller and/or more traditional banks formed a larger part of the banking system (notably Germany, but also Italy and Austria) were those in which the national authorities were more likely to be influenced by the interests of small banks and were more likely to express caution on CMU. We elaborate these points by looking at the 'revealed' preferences of national policy actors - mainly economic interests and public authorities — as expressed in their responses to the Commission consultations and press coverage. These preferences also correspond closely to our expectations, given the business models of these economic interests and their positions within national financial systems and economies.

The main potential winners of CMU were likely to be the most competitive parts of the financial industry, the main transnational players - notably the large universal banks engaged in a range of financial activities including securitisation — insurance companies and the international financial centres in the EU, first and foremost the City of London. In their responses to the Green Paper consultation, large banks and their national representative associations expressed support for CMU (see, for example, British Bankers Association (BBA) 2015, French Banking Federation (FBF) 2015, BNP Paribas 2015). They supported the priority of reviving securitisation and emphasised the need to reduce the post crisis regulatory burden, so as to improve their competitiveness also at the international level.

The proposed revision of the Solvency II Directive — de facto reducing capital requirements for insurers for investments in long term infrastructural projects — would most likely benefit large insurers that were more likely to invest in such projects. The revision of the Prospectus 
Directive and future legislative and non-legislative measures designed to harmonise securities market legislation and ease cross-border activities would be particularly advantageous for the largest, most competitive financial centres - first and foremost the City of London — that would be able to attract more business from around the EU. Other potential beneficiaries of CMU could be SMEs, start-ups, and infrastructural projects. However, the causal chain of effects for these potential beneficiaries was longer than for the first set of immediate winners in the financial sector, and mostly rested on the (uncertain) assumption that additional funding raised on capital markets would reach SMEs, start-ups and infrastructural companies. It is revealing that only 20 per cent of the respondents to the Commission's consultation on the Green Paper were nonfinancial companies and SMEs, only five per cent were NGOs and 1.6 per cent consumer organisations. This suggests that CMU mainly elicited the interest of the financial sector, not economic interests from the so-called 'real economy'.

Many of the potential losers with regard to CMU are less clearly identifiable, in large part because many did not express outright opposition to CMU plans. Potential losers were likely to be domestically focused financial players (smaller banks, stock exchanges, market infrastructure firms), which feared that they might lose out from reinvigorated efforts to harmonise national rules and efforts to encourage consolidation, for example, among stock exchanges. For the head of the German Savings Banks Association (BVD 2015) CMU 'should not come at the cost of traditional bank financing". 2 The German association of small and medium sized non-bank financial firms, Bundesverband der Wertpapierfirmen (BdV 2015: 1), stressed the importance of "a diverse "eco system" of variegated market structures and firms of different size and profile'. The French asset management association (AFG 2015: 1) pointed out that in CMU 'the diversity of European financial places will have to be not only preserved but also developed'. The European Association of Cooperative Banks 
(EACB 2015: 3) aired 'strong concerns regarding the level playing field between capital market oriented companies and non-capital market oriented companies' - points echoed by the European Savings Bank Group (ESBG 2015).

Several member state governments and authorities expressed concern that CMU would disadvantage small banks and that business would move towards the most competitive financial centres in the EU, notably London. The German finance ministry called for 'a simplified regime for small banks specifically adjusted to the needs of financing exclusively smaller enterprises at regional level' (German Finance Ministry 2015: 3). The Bundesbank (2015: 6) argued that 'local bias' was particularly relevant for SMEs and could only to a limited extent be alleviated by CMU. The French Financial Markets Authority (AMF 2015: 2) stated that CMU should not be allowed to harm the 'healthy competition between financial centres'. The Italian government (2015: 2) warned that 'capital will tend to flow to those areas and sectors in the EU, where risk-adjusted returns tend to be higher ... magnifying distortions and unlevelled competitive conditions across Member States in the Single Market'.

\section{The Commission's policy narratives on CMU}

In the design and construction of CMU, the Commission used two main policy narratives, which were supposed to mobilise the potential winners and to appease the potential losers, or those who perceived themselves as benefitting relatively less from CMU. In order to secure political support for the project from a variety of constituencies, the Commission had to speak to and target its message to different audiences. The Commission articulated the first narrative which focused upon boosting the size, the competitiveness and the openness of EU 
capital markets. With this narrative, the Commission mainly targeted the UK, the City of London, large cross-border universal banks and other international financial players. The Commission's second narrative concerned the provision of (non-bank) funding to the real economy, which mainly targeted continental countries and notably countries in the EU periphery, as well as domestically oriented banks and smaller capital markets. Crucially, we have gathered evidence of considerable shifts in the policy narratives adopted by the leading Commission official responsible for promoting the CMU project — depending on the audience addressed.

\section{The policy narrative on boosting EU capital markets and financial centres}

The first policy narrative articulated by the Commission was to 'create a single market for capital for all 28 Member States', increasing its 'competitiveness' and 'openness', 'fostering stronger connections with global capital markets' (Commission 2015a: 5). The Commission claimed to be addressing the problem that capital markets in the EU were 'underdeveloped', 'fragmented' and 'typically organised on national lines' (p. 4). For the Commission, the solution amounted to 'removing barriers to cross-border investment within the EU and fostering stronger connections with global capital markets' (Commission 2015a: 5). Moreover, the Commission argued that CMU was to be built through better regulation, relying mostly on 'market-led bottom up initiatives' (Commission 2015a: 5), so as to promote the competitiveness of the EU financial industry. The second part of this narrative focused on the external dimension of CMU. Hence, CMU should increase the 'global competitiveness and attractiveness of European capital markets' (Commission 2015a: 9). Indeed, the Commission stressed that over the previous decade, European financial centres had lost ground in global competition. 
Apart from the Commission's initial presentation of the CMU project, its main public pronouncements on the importance of CMU in terms of improving the competitiveness of the European financial sector took place in the UK or in specific financial fora (see Table 1). In Commission print media interviews and articles on CMU, competitiveness was emphasised above all in the UK press and financial sector trade magazines. In Germany and France, only a small section of the press — that directed to business, including Les Echos in France ${ }^{3}$ emphasised positively the competitiveness objectives of the project in interviews with the Commission. These newspapers also emphasised the SME and infrastructure finance dimension.

Despite the Commission's focus on improving the competitiveness of all EU financial centres, the concern about the EU's global competitiveness was much higher in the UK (e.g. UK government 2015) than in continental Europe — as indicated by the industry and government responses to the Commission's consultations. For example, policy makers in France focused upon the need to increase the influence of the EU in international financial fora and to regulate more strictly third country access to the EU's single market (French Finance Ministry 2015). No Commission official, speaking in an official capacity to a nonfinance audience in France, Germany or Italy, vaunted the opportunities that the CMU project created in terms of new opportunities for financial sector operators and the competitiveness of European finance. Outside of the UK then, the first narrative was presented only in the context of conferences involving financial sector representatives and experts (see Table 1).

\section{The policy narrative on the provision of (non-bank) funding to the real economy}


The second policy narrative focused upon the provision of (non-bank) funding to the real economy, especially to SMEs and infrastructural projects. The starting point of the narrative was the low economic growth in the EU in the aftermath of the international financial and sovereign debt crises and the limited amount of (bank intermediated) funding available to the real economy. On its webpages and in regular communications on CMU, the Commission argued that bank lending in the EU accounted for an excessively large percentage of total funding to the real economy (75-80 per cent), which was the reverse of the US, ${ }^{4}$ where banks provided only 20 per cent (Commission 2015a) and exposed large parts of the EU economy to a credit crunch in the aftermath of the crisis. The development of EU capital markets offered a solution.

The Commission also presented securitisation as necessary to 'unlocking bank lending' by diversifying funding sources (Commission 2015a). An activist push by the Commission was considered necessary in order to tackle the bad reputation in the EU faced by securitisation, which had more than halved following the international financial crisis. In its explanatory document for the draft legislation on securitisation, the Commission (2015c) distinguished between the massive losses on securitised products sold by US banks and the very small losses on securitised products in the EU. The Commission $(2015 \mathrm{c}: 10,11)$ promised a new 'simple, transparent and standardised securitisation'.

In articulating this policy narrative, the Commission was keen not to alienate the support of or to attract the opposition of the banking sector, and thus CMU was presented as 'complementing the role of banks' (Hill 2015). Indeed, in a joint letter in July 2015, the French and German finance ministers stressed the need 'to ensure a level playing field between the various capital and bank based financial instruments' and that 'banks should be 
an integral part of consideration in this respect' (Schäuble and Sapin 2015: 2). To this end, the Commission committed to undertake a review of existing legislation in order to evaluate the cumulative effects of post crisis legislation on banks and other financial players in the EU. In so doing, the Commission also sought to address the calls by the UK, and the bulk of the EU's financial industry to 'simplify and streamline' EU financial legislation. For example, the UK authorities and almost all the financial industry firms and associations that responded to the consultation made reference to the EU's 'better regulation' agenda.

A systematic review of CMU-focused speeches, interviews and articles by high ranking Commission officials (notably Lord Hill) in Germany and France demonstrates the relative importance attached to emphasising the benefits of CMU (and, specifically, facilitated securitisation) to SMEs and / or infrastructural firms (see Table 1). In France, Lord Hill gave two main policy speeches on CMU: one to a gathering of bankers and one to the wider public with the participation of the then French finance minister, Michel Sapin. In the first speech, Hill emphasised the beneficial impact of CMU for (large universal) banks and the financial sector more generally. In the second speech — which took place at a medium-sized French biotech firm Onxeo in October 2015 - Hill focused entirely upon the impact of CMU on SMEs. No mention was made of the potential benefits to French financial institutions. Indeed, the title of the speech (subsequently placed on the Ministry of Finance web-site) was 'How to encourage the financing of European companies?' (authors' translation) with specific focus on SMEs (Hill and Sapin 2015).

Lord Hill gave only two CMU-focused speeches in Italy. The first, given in December 2014, emphasised the contribution of CMU to investment in infrastructure (Hill 2014). The second, given in December 2015, took place at H-Farm, a start-up incubator firm near Venice, and 
was supported by the presence of the Italian Finance Minister Padoan. This speech focused upon the potential contribution of CMU to the diversification and improvement of SMEfinance. ${ }^{5}$ Lord Hill's CMU-focused speeches and interviews in Germany - apart from those made specifically to the association representing private sector banks - were similarly focused on improved financing opportunities for SMEs and infrastructural projects. ${ }^{6}$ Despite the significant impact of the credit crunch in the UK on SMEs, Lord Hill's presentation of the CMU project in the UK normally side-lined the SME finance dimension with the partial exception of an April 2015 speech to a Reuters Newsmakers' Event which focused on both dimensions of the project.

\section{$<$ Place Table 1 here $>$}

\section{Conclusion}

This paper has examined the making of CMU, arguing that the Commission played a pivotal role at the crucial agenda-setting stage of the project: it conceived the idea, defined what was meant by CMU and set the policy priorities, albeit with input from the member states and industry. The Commission strategically deployed ideas about capital markets liberalisation in order mobilise political support for the project and reduce opposition. The Commission articulated two distinct narratives it used instrumentally to speak to a diverse audience, appealing to those most likely to gain from the CMU project and assuaging the concerns of potential losers (or those perceiving less obvious benefits). The findings outlined in Table 1 demonstrate the use of these two policy narratives in different national contexts and economic interest fora. In the UK and to financial interests, the Commission stressed the contribution of CMU to financial sector competitiveness and opportunities for finance. In 
France and Germany and to smaller banks and nonfinancial companies, the Commission stressed the advantage of CMU to the 'real economy' and notably SMEs and infrastructural firms.

Theoretically, this analysis primarily feeds into the ideas-based literature on EU public policy. From the 1980 s to the 2000s, the Commission pursed a political strategy in manipulating a number of distinct discourses on the market in the 1980s and 1990s to attract the support of very different socio-economic groups and member states to market integration (Jabko 2006). We highlight the continuity in this strategy to the recent past by way of the Commission's use of two distinct policy narratives on the construction of CMU from 2015 onwards. It should be noted that the evidence provided in this piece does not prove definitively the existence of strategic motives on the part of Commission officials. Furthermore, we are unable to prove whether the Commission's narratives were also, at least in part, cognitive maps for policy-makers (à la Parsons 2002) — in other words, that actors genuinely believed in them - or served as 'coordinative discourses' amongst supranational and national policy elites (à la Schmidt 2008). What we can show, however, is that the evidence from speeches, interviews and articles written principally by and for Lord Hill demonstrates a very strong pattern in the representation of specific features of the CMU project, its objectives and potential benefits. This strong pattern involved two distinct narratives and suggests the adoption of a strategy by Commission officials. Based on the argument presented in this paper, the resignation of Lord Hill from the Commission in 2016 should not per se result in a significant shift in this Commission strategy. However, Brexit will likely result in a shift in the narratives that the Commission wields to legitimise the development of further elements of the CMU project, now that there is less need to 'entice' 
the British government and financial interests to support the project. Further research in this direction would be welcome.

Finally, an interesting research agenda stems from these findings both theoretically and, more practically, for policy. Theoretically, it would be important to investigate why the Commission and its narratives are influential in certain policy areas, such as in the case of CMU, while in other areas they are not, as in the case of Banking Union. As for the policy debate, the political economy effects of CMU and distributional conflicts will become clearer once additional legislative measures are negotiated and implemented. Hence, future research could investigate whether the influence of the Commission through its strategic use of narratives will continue once these additional pieces of legislation are proposed and negotiated.

\section{Disclosure statement}

No potential conflict of interest was reported by the authors.

\section{Notes on contributors}

Lucia Quaglia is Professor of Political Science at the University of Bologna;

lucia.quaglia@unibo.it

David Howarth is Professor of Political Economy at the University of Luxembourg; david.howarth@uni.lu 


\section{References}

Abdelal, R., Blyth, M. and Parsons, C. (2010) Constructing the International Economy, Ithaca. NY: Cornell University Press.

Armstrong, K. and Bulmer, S. (1998) The Governance of the Single European Market, Manchester: Manchester University Press.

Association Française de la Gestion financière (AFG) (2015) 'Response to the Commission's Consultation on the Green Paper on CMU'. https://ec.europa.eu/eusurvey/publication/capitalmarkets-union-2015? language $=\mathrm{en}$.

Autorité des Marchés Financiers (AMF) (2105) 'Response to the Commission's Consultation on the Green Paper on CMU'. https://ec.europa.eu/eusurvey/publication/capital-marketsunion-2015.

Bickerton, C., Hodson, D. and Puetter U. (eds) (2015) The New Intergovernmentalism, Oxford: Oxford University Press.

BNP Paribas (2015) 'Response to the Commission's Consultation on the Green Paper on CMU'. https://ec.europa.eu/eusurvey/publication/capital-markets-union-2015? language $=\mathrm{en}$. 
British Bankers Association (BBA) (2015) 'Response to the Commission's Consultation on the Green Paper on CMU'. https://ec.europa.eu/eusurvey/publication/capital-markets-union2015? language $=\mathrm{en}$.

Bundesbank (2015) 'Response to the Commission's Consultation on the Green Paper on CMU'. https://ec.europa.eu/eusurvey/publication/capital-markets-union-2015? language=en.

Bundesverband der Wertpapierfirmen (BdV) (2015) 'Response to the Commission's Consultation on the Green Paper on CMU'. https://ec.europa.eu/eusurvey/publication/capitalmarkets-union-2015? language $=\mathrm{en}$.

Carstensen, M.B. and Schmidt, V.A. (2015) 'Power Through, Over and In Ideas: Conceptualizing Ideational Power in Discursive Institutionalism', Journal of European Public Policy 23 (3): 318-337.

TheCityUK (2015) 'Capital Markets Union: The perspective of European growth companies'. http://www.ey.com/Publication/vwLUAssets/ey-capital-markets-union-theperspective-of-european-growth-companies/\$FILE/ey-capital-markets-union-the-perspectiveof-european-growth-companies.pdf.

Commission (2015a) 'Green Paper: Building a Capital Markets Union', COM(2015) 63 final, 18 February. http://eur-lex.europa.eu/legalcontent/EN/TXT/PDF/?uri=COM:2015:63:FIN\&from=EN. 
Commission (2015b) ‘Action Plan on Building a Capital Markets Union', COM(2015) 468 final, $\quad 30 \quad$ September. $\quad$ http://eur-lex.europa.eu/legal-content/EN/TXT/PDF/? uri=CELEX:52015DC0468\& from=EN.

Commission (2015c) 'Simpler Securitisation', $30 \quad$ September. http://ec.europa.eu/finance/capital-markets-union/docs/simpler-securitisation_en.pdf.

Confederation German Industry (BDI) (2015) 'Response to the Commission's Consultation on the Green Paper on CMU'. https://ec.europa.eu/eusurvey/publication/capital-marketsunion-2015?language $=$ en.

Donnelly S. (2010) The Regimes of European Integration, Oxford: Oxford University Press.

Egan, M. (2001) Constructing a European Market, Oxford: Oxford University Press.

Epstein, R. (2017) Banking on Markets, Oxford: Oxford University Press.

European Central Bank (ECB) (2012) Financial Integration Report, April, Frankfurt: ECB.

European Association of Cooperative Banks (EACB) (2015) 'Response to the European Commission's Green Paper on "Building a Capital Markets Union'. https://ec.europa.eu/eusurvey/publication/capital-markets-union-2015?language=en.

European Saving Banks Group (ESBG) (2015) 'Response to the Commission's Green Paper on CMU'. http://www.savings-banks.com/press/positions/Pages/capital-markets-union.aspx. 
Five Presidents Report (2015). Completing Europe's Economic and Monetary Union, Brussels: European Commission. https://ec.europa.eu/priorities/sites/beta-political/files/5presidents-report_en.pdf.

Fédération Bancaire Française (FBF) (2015) 'Response to the Commission's Consultation on the Green Paper on CMU'. https://ec.europa.eu/eusurvey/publication/capital-markets-union2015? language $=$ en .

French Finance Ministry (2015) 'Response to the Commission's consultation on the Green Paper on CMU'. https://ec.europa.eu/eusurvey/files/99621bcb-cbc1-4673-ae30da39f4e0b61e.

German Government (2015) 'Response to the Commission's consultation on the Green Paper on CMU'. https://ec.europa.eu/eusurvey/publication/capital-markets-union-2015.

Hill, J. (2014) 'Building to last: boosting long-term investment in Europe', at the Conference on Investing in Long-Term Europe: Re-Launching Fixed, Network and Social Infrastructure, Rome, 12 December 2014. http://europa.eu/rapid/press-release_SPEECH-14-2626_en.htm.

Hill, J. (2015a) 'For a financial sector that promotes investment'. Speech to the City of London Corporation Policy Committee, 15 July 2015, London. http://europa.eu/rapid/pressrelease_SPEECH-15-5380_en.htm. 
Hill, J. (2015b) 'Introductory remarks by Commissioner Jonathan Hill at the launch of the Capital Markets Union Action Plan', 30 September. http://europa.eu/rapid/pressrelease_SPEECH-15-5749_en.htm.

Hill, J. and Sapin, M. (2015) 'Comment Favoriser le financement des entreprises européennes ?', French Ministry of Finance, 12 October, Paris. http://proxypubminefi.diffusion.finances.gouv.fr/pub/document/18/19848.pdf.

Howarth, D. and Quaglia, L. (2016), The Political Economy of Banking Union, Oxford University Press, Oxford.

Italian Ministry of the Economy and Finance (2105) 'Building a Capital Markets Union: Italy's views on the Commission Green Paper'. https://ec.europa.eu/eusurvey/publication/capital-markets-union-2015.

Jabko, N. (2006) Playing the Market: A Political Strategy for Uniting Europe, 1985-2005, Ithaca: Cornell University press.

Jabko, N. (1999) 'In the Name of the Market: How the European Commission Paved the Way for Monetary Union', Journal of European Public Policy 6 (3): 475-95.

Juncker, J-C. (2014) Political Guidelines for the Next Commission, 15 July. http://www.eesc.europa.eu/resources/docs/jean-claude-juncker-political-guidelines.pdf. 
McNamara, K. (1998) The Currency of Ideas: Monetary Politics in the European Union, Ithaca: Cornell University Press.

Mügge, D. (2010) Widen the Market, Narrow the Competition: Banker Interests and the Making of a European Capital Market, Colchester: ECPR.

Mügge, D. (2011) 'From Pragmatism to Dogmatism. EU Governance, Policy Paradigms, and Financial Meltdown', New Political Economy 16 (2): 185-206.

Parsons, C. (2002) 'Showing Ideas as Causes: The Origins of the European Union', International Organization 55 (1): 47-84.

Quaglia, L. (2012) 'The "old" and "new" politics of financial services regulation in the European Union', New Political Economy 17 (4): 515-535.

Quaglia, L. (2010) Governing Financial Services in the European Union, London: Routledge.

Quaglia, L., Howarth, D. and Liebe, M. (2016) 'The Political Economy of Capital Markets Union', Journal of Common Market Studies 54 (s1): 185-203.

Radaelli, C.M. (1999) 'Harmful Tax Competition in the EU: Policy Narratives and Advocacy Coalitions', Journal of Common Market Studies 37 (4): 661-682.

Radaelli, C. and Dunlop, C. (2013) 'Learning in the European Union: Theoretical Lenses 
and Meta-Theory', Journal of European Public Policy 20 (6): 923-940.

Ringe W.G. (2015) 'Capital Markets Union for Europe - A Political Message to the UK', Oxford Legal Studies Research Paper No. 26/2015, March.

Sabatier, P.A. (1998) 'The Advocacy Coalition Framework: Revisions and Relevance for Europe' Journal of European Public Policy 5 (1): 98-130.

Saurugger S. (2013) 'Constructivism and Public Policy Approaches in the EU: From Ideas to Power Games' Journal of European Public Policy 20 (6): 888-906.

Schäuble, W. and Sapin, M. (2015) "Letter". http://www.economie.gouv.fr/fi les/files/PDF/2015-07-06_letter-about_capital-markets-union_6-july-2015.pdf. Last accessed: 10 August 2016.

Schimmelfennig, F. (2015) 'Liberal Intergovernmentalism and the Euro Area Crisis', Journal of European Public Policy, 22 (2): 177-95.

Schmidt, V.A. (2008) 'Discursive Institutionalism: The Explanatory Power of Ideas and Discourse, Annual Review of Political Science 11: 303-26.

Schmidt, V.A., Radaelli C.M. (2004) 'Policy Change and Discourse in Europe: Conceptual and Methodological Issues', Journal of Public Policy 27 (2): 183-210. 
Surel, Y. (2000) 'The Role of Cognitive and Normative Frames in Policy Making' Journal of European Public Policy 7 (4): 495-512.

UK Government (2015) 'Response to the Commission's Consultation on the Green Paper on CMU'. https://ec.europa.eu/eusurvey/files/634a485d-8dd9-41e6-af91-030013307436. Last accessed 13 May, 2017.

Véron, N. (2014) 'Defining Europe's Capital Markets Union’ Bruegel Policy Contribution, No. $2014 / 12$.

\section{NOTES}

${ }^{1}$ For constructivist approaches in international political economy, see Abdelal, Blyth and Parsons (2010).

${ }^{2}$ EU warned not to let capital markets union hurt role of banks', Financial Times, 23 August 2015.

3 'Union des marchés de capitaux: profitable, mais pas sans risque', Les Echos, 2 September 2015.

${ }^{4}$ It should be noted that the German and French finance ministers explicitly questioned the advisability of emulating the US financial system in the European context (Schäuble and Sapin 2015; French Minister of Finance 2015; German Finance Ministry 2015).

5 'Padoan : Il Governo valuta sostegno fasce deboli, non compensazione credito', Corriere Del Veneto, 4 December 2015; 'Hill: Più prestiti alle piccole imprese le banche si devono attivare in fretta', la Repubblica, 14 December 2015. 
6 See, for example, Lord Hill's speech to CDU-CSU parliamentarians: Die Rahmenbedingungen für kleine und mittlere Kreditinstitute stärken', CDU-CSU Fraktion im Deutschen Bundestag, 7 May 2015. https://www.cducsu.de/themen/wirtschaft-und-energiehaushalt-und-finanzen/die-rahmenbedingungen-fuer-kleine-und-mittlere-kreditinstitutestaerken. 
Table 1: Commission speeches, interviews and articles on Capital Markets Union (September 2014 to September 2016)*

\begin{tabular}{|c|c|c|c|c|c|}
\hline & \begin{tabular}{|l} 
Only on \\
financial sector \\
opportunities / \\
competitiveness
\end{tabular} & $\begin{array}{lr}\text { Principally } & \text { on } \\
\text { financial } & \text { sector } \\
\text { opportunities } & / \\
\text { competitiveness } & \end{array}$ & Equal focus & $\begin{array}{l}\text { Principally on SMEs and / or } \\
\text { infrastructure funding }\end{array}$ & $\begin{array}{l}\text { Only on SMEs and / or } \\
\text { infrastructure funding }\end{array}$ \\
\hline UK & & $\begin{array}{l}\text { 4: Financial Times; } \\
\text { Reuters Newsmakers; } \\
\text { FT-Live; } \text { LSE }^{1}\end{array}$ & $\begin{array}{l}\text { 1: Parliament } \\
\text { Magazine }^{2}\end{array}$ & & \\
\hline Germany & & & & 2: Handelsbaltt, SD Zeitung ${ }^{3}$ & $\begin{array}{l}3 \text { (incl. } 1 \text { to } \mathrm{CDU} / \mathrm{CSU} \\
\text { representatives }{ }^{4} \text { ) }\end{array}$ \\
\hline France & & & & 1: Décideurs Magazine ${ }^{5}$ & $\begin{array}{l}\text { 1: speech to Oxneo } \\
\text { (SME) }\end{array}$ \\
\hline $\begin{array}{l}\text { Finance } \\
\text { (non- } \\
\text { bank) }\end{array}$ & $\begin{array}{l}\text { 1: TheCity UK } \\
\text { (London) }^{6}\end{array}$ & $\begin{array}{lr}\text { 5: Pensions } & \text { Europe } \\
\text { (Brussels) } ;^{7} & \text { Capital } \\
\text { Markets } & \text { (Brussels) }{ }^{8} \\
\text { Managed } & \text { Funds } \\
\text { Association (Brussels) }{ }^{9} & { }^{2} \\
\text { SIFMA (New } & \text { York) }{ }^{10} \\
\text { European Chamber of } \\
\text { Commerce } \\
\text { Kong) }\end{array}$ & $\begin{array}{l}1: \text { Frankfurt } \\
\text { Finance }\end{array}$ & & \\
\hline $\begin{array}{l}\text { Finance } \\
\text { (Bank) }\end{array}$ & $\begin{array}{l}\text { 5: CityUK } \\
\text { (London) }{ }^{13} \\
\text { Banking } \\
\text { (Paris) }{ }^{14} \\
\text { Bankers } \\
\text { association } \\
\end{array}$ & $\begin{array}{l}\text { 2: BDB (Frankfurt and } \\
\text { Stuttgart) }\end{array}$ & $\begin{array}{ll}1: & \text { ESBG } \\
(\text { Brussels })^{19} & \end{array}$ & & \\
\hline
\end{tabular}




\begin{tabular}{|c|c|c|c|c|}
\hline & $\begin{array}{l}\text { (Copenhagen); }{ }^{15} \\
\text { EBF } \\
\text { (Brussels); }{ }^{16} \\
\text { Borsen Zeitung } \\
\text { (Frankfurt) }^{17}\end{array}$ & & & \\
\hline $\begin{array}{l}\text { Finance } \\
\text { (all) }\end{array}$ & $\begin{array}{l}\text { 2: The City of } \\
\text { London }^{20}\end{array}$ & $\begin{array}{l}\text { 1: } \\
(\text { Brussels) })^{21}\end{array}$ & & \\
\hline $\begin{array}{l}\text { Small } \\
\text { (public) } \\
\text { banks }\end{array}$ & & & 1: SparkassenZeitung ${ }^{22}$ & $\begin{array}{l}\text { 2: } \quad \text { EACB } \\
\text { Germany }^{23}\end{array}$ \\
\hline SMES & & & $\begin{array}{l}\text { 2: } \quad \text { European } \quad \text { Business } \\
\text { (Bruges); LSE (London) })^{24}\end{array}$ & $\begin{array}{l}\text { 4: EP } \quad \text { (Brussels); } \\
\text { Germany; France; }{ }^{25} \text { H- } \\
\text { Farm (Italy) }\end{array}$ \\
\hline
\end{tabular}

*These speeches, printed interviews and written articles exclude those made from Brussels during the launch of a new report on CMU or draft directive (etc.) on an element of the CMU project or any Commission sponsored conference in Brussels. These speeches (etc.) are made in the member state(s) in question and / or to companies in the sectors in question. Only speeches (etc.) published and made available publicly are included. No speeches (etc.) which include CMU as one of several topics are included. No Brexit-focused speeches (etc.), in which CMU might be highlighted are included. All but one of these speeches (etc.) were made by Lord Hill.

${ }^{1}$ Hill, J. ‘A stronger capital markets union for Europe', Financial Times, 29 September 2015. Hill, J. 'Speech at Reuters Newsmaker's Event: The Capital Markets Union: breaking down the barriers to completing the single market', 17 April 2015, London, http://europa.eu/rapid/pressrelease_SPEECH-15-4796_en.htm; Hill, J. 'LSE Public Lecture: The Single EU Capital Market: progress and challenges', 23 May 2016, London, http://www.lse.ac.uk/website-archive/newsAndMedia/videoAndAudio/channels/publicLecturesAndEvents/player.aspx?id=3510; Hill, J. 'Future 
of Europe Leadership Series', Financial Times, FT-Live, 27 November 2015. https://live.ft.com/Events/2015/FT-FUTURE-OF-EUROPE-

\section{LEADERSHIP-SERIES.}

${ }^{2}$ Hill, J. 'A stronger capital markets union for Europe', Financial Times, 29 September 2015; Singh, J. 'Money Talks: EU Commissioner Jonathan Hill on how Europe can recover from the financial crisis', The Parliament Magazine, 18 November 2015.

3 'Hill: Sehr große Banken bergen noch Risiken', Handelsblatt, 28 April 2015; 'Banken waren im Auge des Sturms', Süddeutsche Zeitung, 17 March 2015.

${ }^{4}$ Hill, J. 'Die Rahmenbedingungen für kleine und mittlere Kreditinstitute stärken', CDU-CSU Fraktion im Deutschen Bundestag, 7 May 2015. https://www.cducsu.de/themen/wirtschaft-und-energie-haushalt-und-finanzen/die-rahmenbedingungen-fuer-kleine-und-mittlere-kreditinstitutestaerken

${ }^{5}$ Hill, J. 'Pour une titrisation basée sur la simplicité, la transparence et la standardisation', Décideurs magazine, 9 July 2016.

6 Hill, J. 'Speech to TheCityUK Annual Conference: Building a stronger single market in capital', 30 June 2015 , London. http://europa.eu/rapid/press-release_SPEECH-15-5290_en.htm.

7 Hill, J. 'Speech at the Pensions Europe Conference 2016', 23 June 2016, Brussels. http://europa.eu/rapid/press-release_SPEECH-162324_en.htm

${ }^{8}$ Hill, J. 'Speech at the 2015 ECMI Annual Conference: Europe's Capital Markets Union'; 20 October 2015, Brussels. http://europa.eu/rapid/pressrelease_SPEECH-15-5870_en.htm. 
${ }^{9}$ Managed Funds Association and Politicos, 'Capital Markets Union Breakfast with Lord Jonathan Hill'. http://www.politico.eu/event/capitalmarkets-union-breakfast/

10 Hill, J. 'Speech given at Securities Industry and Financial Markets Association (SIFMA)' 27 February 2015 , New York. http://europa.eu/rapid/press-release_SPEECH-15-4523_en.htm

${ }^{11}$ Hill, J. 'Speech at the European Chamber of Commerce and ASIFMA, 12 November 2015, Hong Kong, http://europa.eu/rapid/pressrelease_SPEECH-15-6076_fr.htm

12 Hill, J. 'Speech at the Frankfurt Finance Summit How to restart growth', 17 March 2015, Frankfurt, http://europa.eu/rapid/pressrelease_SPEECH-15-4616_en.htm

13 Hill, J. 'Speech to TheCityUK Annual Conference: Building a stronger single market in capital', 30 June 2015, London, http://europa.eu/rapid/press-release_SPEECH-15-5290_en.htm

${ }^{14}$ Hill, J. 'Keynote speech at the Economist's Future of Banking Summit', 10 March 2016, Paris, http://europa.eu/rapid/press-release_SPEECH16-726_en.htm

${ }^{15}$ Hill, J. 'Speech at the Danish Bankers' Association, Copenhagen', 4 March 2016, Copenhagen, http://europa.eu/rapid/press-release_SPEECH16-588_en.htm

${ }^{16}$ Hill, J. 'Speech at European Banking Federation,: A Brave New World for Banks', 17 September 2015, Brussels, http://europa.eu/rapid/pressrelease_SPEECH-15-5673_en.htm 
17 'Im Interview: Jonathan Hill, EU-Commission', Börsen-Zeitung, 31 March 2015, N. 62.

${ }^{18}$ Hill, J. 'Die Kapitalmarktunion - Chance für die europäische Wirtschaft?'. 4 March 2015, Frankfurt, https://bankenverband.de/was-wirtun/veranstaltungen/gespraech-in-der-burgstrasse/die-kapitalmarktunion-chance-fur-die-europaische-wirtschaft/; Hill, J. 'Speech at the Bankenverband Deutschland (BDB)', Baden-Württemberg, 9 November 2015, Stuttgart.

19 Katainen, J. 'Speech by Jyrki Katainen, Vice President of the European Union', ESBG Retail Banking conference, Brussels, Royal Windsor Hotel, 19 March 2015, https://www.wsbi-esbg.org/SiteCollectionDocuments/Speech\%20VP\%20Katainen.pdf

${ }^{20}$ Hill, J. 'Speech at the City of London: For a Financial Sector that Promotes Investment', Speech to the City of London Corporation Policy Committee, 15 July, 2015, London, http://europa.eu/rapid/press-release SPEECH-15-5380 en.htm'; Hill, J., 'Speech to the City of London', 1 December 2015, London.

${ }^{21}$ Hill, J. 'Speech at the Euromoney Capital Markets Union Forum: Building a Capital Markets Union', 3 December 2015, Brussels, europa.eu/rapid/press-release_SPEECH-15-6244_en.pdf

${ }^{22}$ Hill, J. 'Kapitalmarktunion Interview: Vernünftig und mit Augenmaß’, Die Sparkassen Zeitung, 8 May 2015, N. 19, S. 4.

${ }^{23}$ Hill, J. 'Speech at the Convention on Cooperative Banks in Europe', 3 March 2015, Brussels, http://europa.eu/rapid/press-release_SPEECH15-4537_en.htm. 
${ }^{24}$ Hill, J. 'Speech at the Bruges European Business Conference: Capital Markets Union', 18 March 2016, Brussels, http://europa.eu/rapid/pressrelease_SPEECH-16-921_en.htm; Hill, J. 'Speech at the launch of the 1000 companies at the London Stock Exchange', 15 June 2016 , London, http://www.lseg.com/resources/1000-companies-inspire-britain/nurturing-growth-europe.

${ }^{25}$ Hill, J. and Sapin, M. (2015) ‘Comment Favoriser le financement des entreprises européennes ?’ French Ministry of Finance, 12 October, Paris.

${ }^{26}$ See footnote 6 . 